\title{
RHIZOMATIC COSMOPOLITAN AND WILSONIAN RECURSIVE VISION IN JOE TURNER'S COME AND GONE
}

\author{
Roksana Dayani, Shiraz University, Iran, roxanadayani@gmail.com \\ Bahee Hadaegh, Shiraz University, Iran, bhadaegh@shirazu.ac.ir
}

Original scientific paper

DOI: $10.31902 /$ fll.32.2020.1

UDC: 821.111(73).09-2

\begin{abstract}
Being the constant wanderer for the lost identity in the polyethnic land of America, African Americans bear striking resemblance to the figure of flâneur with dialectical image of local and cosmopolitan citizen of the universe. The spirit of flânerie proves its geographical historical expansion in both postmodern and African American context while its performative action navigates it in dramatic texts. Hence, Wilsonian characters identical with constant existential quest for the lost self can be African American incarnations of flâneur. Drawing on Baudelaire's definition and Benjamin's theory of flâneur, this study seeks to demonstrate possible manifestations of African American flâneur in August Wilson's Joe Turner's Come and Gone (1986). Moreover, through Deleuze and Guattari's postmodern theoretical concept of rhizome in A Thousand Plateau (1987), the study aims to explore the postmodern manifestation of flâneur and consequently manifest how it functions to be the means for Wilsonian postmodern recursive dramatic vision that represents mysterious aspects of African Americans life. Flâneur's versatility appropriates it to be the quintessential manifestation of African Americans inasmuch as the latter's multifaceted African nature can accommodate the former's flexibility.
\end{abstract}

Keywords: August Wilson, Baudelaire's flâneur, Benjamin's flâneur, Deleuze and Guattari's A Thousand Plateau, Joe Turner's Come and Gone, rhizome.

\section{INTRODUCTION}

Flâneur, as one of the most fascinating figures undergoing various temporal/spatial metamorphoses from European to American culture, is a recurring motif in the Literary, Social, and Urban/Cultural Studies. The figure of flâneur was first described by Baudelaire in The Painter of Modern Life (1863) and was poetized in his famous poems Le Spleen de Paris (1869), Les Fleurs Du Mal (1857). Then, it was developed and theorized in Benjamin's study of late nineteenth and early twentiethcentury European urban modernity mirrored in The Arcades Project (1999). Reading Baudelaire and arguing about his struggle to find a 
secure place for flâneur in the rational and capitalist Paris, Benjamin challenged flâneur's existence (Tester 13). To Benjamin, the rationalization and commodification of capitalism ceased Paris to be a place of wonder for flâneur, who was immersed by the proliferations of images of marketplace instead of remaining the distance observer (Rechniewski 92-93). Furthermore, he was "bounded in the crowd" as an isolated passive figure with a nostalgic look in contrast to Baudelaire's flâneur feeling intoxicated and at home in the chaotic life of the crowd (Benjamin 85; Feste 11-12). Therefore, flâneur became the existence "out of step with the rapid circulation of modern metropolis" and died (Tester 15). Nevertheless, reappearance of flâneur in postmodern writings and publications remarkably proved its revival, versatility and challenged its historical specificity. If modernity turned the sedentary culture of Paris of 19th century into nomadic nature and flourished the phenomenon of flânerie, the more fluid postmodern living conditions would confirm flâneur's re-emergence and expansion in a new form. Thus, as a new form, it can be transformed into the "transnational figure" (Lee 6). We can trace the postmodern incarnations of flâneur in different works such as Auster's In the Country of Last Things, José Cardoso Pires's Lisboa: Livro de Bordo, Edmund White's The Flâneur, Kirby and Woodman's picture book The Cows Are Going to Paris, Morrison's Jazz, Yan Lian's poetry and Woody Allen's Midnight in Paris, to name but the few. Therefore, this list can exemplify not only flâneur's temporal-spatial expansions but also his evolution to generic figure. In this sense, he has passed the modern Paris of nineteenth century as a social figure to the modern and postmodern fiction, poetry, and film as a literary figure.

As such, its trans-regional mode of existence presumably calls for the transnational identity of many immigrants wandering in the host land. The sense of displacement and the constant wanderer in search for the lost are what constitute the common thematic structure of diaspora, especially of African American literature (Ibrahim 2008; Prece 2008). Accordingly, we can claim that walking is performed as the everyday practice of African Americans roaming in sharply delineated urban landscape. Nevertheless, with the advent of Enlightenment, being associated with people of color, that wandering has been considered criminal (Cervenak 15-35). Notwithstanding the representation of African American flâneur in social and cultural studies, the significant inquiry is how African American flâneur as a literary figure can be represented or even appropriated by different writers. Or, regarding the racially restricted cosmopolitan landscape of United States, to what extent African American flâneur has 
coterminous relationship with Baudelaire and Benjamin's flâneur. Flâneur is an urban wandering observer, a philosopher; a connoisseur with perceptive attitude and insatiable desire for being in the crowd. Flâneur's scrutinizing eyes have the power of interpreting people's face, analyzing various aspects of life as he is in the existential attempt to have self-definition (Benjamin 400, 414-429; Tester 8-9). Among African American works concentrating on wandering questing immigrant is August Wilson's Joe Turner's Come and Gone (1986) as "signature play" of his Pittsburg Cycle (Shannon 189) which dramatizes African Americans identity and their nomadic lifestyle.

\section{REVIEW OF LITERATURE}

Referring to the proper accommodation of flâneur in Wilson's plays, we can testify flâneur's compatibility with dramatic context when we are informed of its performative role played in the city as his "theatrical display, an arena" (Benjamin 347; Schipper 193). Moreover, it is in intriguing association with performative identity of Wilsonian wanderers in a way that requires their identity to be in endless process of negotiation with self and others (Clark 52). Thus, Wilsonian character can be the flâneur who is the actor and performer in the theater of cosmopolitan city. Nevertheless, flâneur has rarely been the central topic of dramatic text. Even, flâneur as a theoretical lens for portraying the modern and postmodern urban landscape of a society (Castro 2009; Lane 2002) or a fictional world (Kula 2018; Steinman 2014) has attracted many critics' attention. No single study concentrates on the literary figure of flâneur to comprehensively investigate it in the postmodern African American drama. The theatricality of flâneur and its possible applicant in drama have been mentioned only by Schipper (2017). She concisely discusses flâneur as the performative spectator, actor and coproducer in the theater of city, the study which is only helpful in media dramaturgy. A case in point can be Cervenak's examination of the concept of wandering, not the flâneur itself, as a philosophical performance of racial and sexual freedom with particular analysis of Kennedy's plays. Her study opens up new opportunity for expanding the concept into the figure of flâneur especially in African American drama. Conversely, by calling the figure of postcolonial as counter flâneur, Suárez (2016) argues about the impossibility of navigating flâneur's manifestations due to the reversal effect of the realities of global city in rendering flâneur obsolete. Yet, Suárez's content on the concept of counter flâneur can be thought-provoking from Deleuze and Guattari's perspective. Accordingly, this perspective disclaims any privileged subject of the 
Platonic model of representation and thus any origin or copy. In this sense, it can imply the multiple manifestations of flâneur regardless to binary opposition of American/African identity (8).

The immense scholarly works on Joe Turner's Come and Gone reveal multifaceted critical discourses and also offer insightful discussions on characterization of its pivotal characters Bynum and Loomis (Richards 1999, Rudolph 2003, Larue 2010, and Nadel 2010). Nevertheless, few of them afford to concentrate specifically on the wandering statue and behavioral details of each character to identify them with prominent features of flâneur. All of these justifications necessitate present study's concentration on dramatic context to examine contemporary African American wanderers as the possible manifestations of flâneur in August Wilson's aforementioned play. What has legitimated the investigation of postmodern manifestation of flâneur is Wilson's postmodern dramatic vision for reconsidering African American tradition hailing him as the "leading figure in a New Age Post-Revolutionary developmental epoch" (Pinkney 26-27). Drawing on Baudelaire's and Benjamin's definition of flâneur in The Painter of Modern Life (1863) and The Arcades Project (1999), the main objective of this study is to identify the figure of flâneur in African American context of Joe Turner's Come and Gone. Then, applying Deleuze and Guattari's postmodern, nomadological approach in A thousand Plateaus: Capitalism and Schizophrenia (1987), this study will investigate how Wilson has represented his African American characters as postmodern manifestations of flâneur.

Joe Turner's Come and Gone is the third of the sequence in Pittsburgh Cycle setting in Pittsburgh Pennsylvania of 1911. Having the central concept of flâneur in mind, we find Wilson's description of these "itinerant folks" significant: "[...] wander from the deep and near South the sons and daughters of newly freed African slaves" (Snodgrass 120, xvii). These "wandering ex-slaves" (Nadel 14) are struggling to redefine their historical and social status as a free citizen in polyethnic American society (Bogumil 465). Their attempts "to give luminous meaning to [...] their song" and to redefine their identity evoke flâneur's insatiable desire for searching and his "existential attempt to discover the secret of being" in the metropolitan world (Wilson 1988, xvii; Bogumil 465; Tester 8). In order to explore the African American manifestations of flâneur in two pivotal characters Bynum and Loomis, the focus of first section is on identifying African American flâneurs, on illustrating how gaining Wilsonian Africanism is in close correlation with being flâneur. Finally, the focus will be on 
exploring postmodern manifestation of these characters through adopting Deleuze and Guattari's methodology.

\section{DISCUSSION}

I. Cosmopolitan Flaneur; Bynum Walker

In the Painter of Modern Life, flâneur is defined as a "great traveler" and "cosmopolitan" (Baudelaire 6-7). these features license flâneur's possible geographical and cultural transgression to be the incarnation of African American wanderer in the cosmopolitan America Moreover, flâneur is an urban wandering observer to whom "what is matter is the human being, community to the extent that his profession and passion are to become one flesh with the crowd" (Ibid. 5-9; Benjamin 425). With this in mind, Bynum Walker's narration of his past life indicates wandering and roaming as his routine action to the extent that he seems to be a commissioner:

You going upriver, huh? You going up around my way. I used to go all up through there. Blawknox ... Clairton. Used to go up to Rankin and take that first righthand road. I wore many a pair of shoes out walking around that way. You'd have thought I was a missionary spreading the gospel the way I wandered all around them parts. (Wilson 1988, 45)

Obvious is the fact that Bynum is not a perplexed immigrant desperately searching for his lost identity. Instead, his lifestyle denotes that he has passed a long way wandering until his present status dwells in temporary lifestyle of wandering. Seth Holly's description of Bynum also sounds remarkable: "He's one of them fellows never stay in one place. He was wandering all around the country till he got old and settled here" (Ibid. 36). In like manner, his name Walker epitomizes flânerie in a way that he is "identity seeker through mysticism" in encounter with others, "the rover enervated by years on the road" (Snodgrass 121). as Also, Bynum himself states that "I used to travel all up and down this road and that [...] looking here and there searching" (Wilson 72). More to say, "Phantasmagoria of flâneur to read from faces the profession, the ancestry, and the character" (Benjamin 429) has obvious manifestations in Bynum's appreciation of Loomis' contradictory mental situation, interpretation of vision of bones as African ancestors (Wilson 54-55) and also more vividly in realizing Loomis's profession:

BYNUM: I can tell from looking at you. My daddy taught me how to do that. Say when you look at a fellow, if you taught yourself to look for it, you can see his song written on him. Tell 
you what kind of man he is in the world. Now, I can look at you, Mr. Loomis, and see you a man who done forgot his song. (Wilson 71-2)

In this sense, Bynum is the same "moralist", "philosopher" and "connoisseur" "gifted with the power of analysis", enabling him to "understand the whole world and the mysterious and lawful reasons for all its uses" (Baudelaire 5-12). It is not far-fetched to note that it is his "powerful insight" that assigns him as a "spiritual healer" (Bogumil 471). He is a biding man who binds others together and wisely advices them to find their specific song as a way of finding self (Scott 20):

I had the Binding Song. I choose that song because that's what I seen most when I was traveling [...] people walking away and leaving one another. So, I take the power of my song and binds them together. [...]That's why they call me Bynum. (Wilson 11)

Moreover, Baudelaire's definition of flâneur characterized with "eagle eyes seeing, examining and analyzing the external aspect of the things" has found incarnation in Bynum's usual actions of killing and burying pigeon and sprinkling blessing salt all over the house (12; Wilson 2-3). In addition, being called "mumbo jumbo nonsense", "heebie-jeebies stuff" and "the damndest thing" by Seth, all of these strange doings evoke flâneur's similarity to the child (Ibid). Flâneur is similar to child for "being possessed in the highest degree of faculty of keenly interesting himself in things, be they apparently of the most trivial" (Baudelaire 7). Not only do all of these seemingly trivial things refer to "respatializing" African ritual, but also in combination with Bynum's "genius" as flâneur, "no aspect of life has become stale" for him (Baudelaire 9; Scott 18). Flâneur's "insatiable passion for [...] things of metaphysician" propels him to find the significance of holding African identity in rituals for which Seth pays no mind and care (Ibid). Bynum's involvement in African rituals and metaphysics can significantly entail its flânerie passion in extracting eternal from temporal. Therefore, this seemingly banal temporality is the spiritual conduit for African American flâneur to find his eternal meaning of self.

In this sense, Wilson's stage description of Juba dance performed on Sundays by characters comes noteworthy:

The Juba is reminiscent of the Ring Shouts of the African slaves. It is a call and response dance. BYNUM sits at the table and drums. He calls the dance as others clap hands, shuffle and stomp around the table. It should be as African as possible, with the performers working 
themselves up into a near frenzy. The words can be improvised, but should include some mention of the Holy Ghost. (53)

Accordingly, Bynum's readiness for dancing and his role of leading the performance precisely indicate Wilson's strategy of fashioning dance as a performative vehicle for articulation of the self (Clark 52). The performative conduit through which he can construct his characters required performative identity to be set in negotiation and communication with others (Ibid). It is significant that Wilson's strategy of performative process of self-identification testifies flâneur's "insatiable appetite for non-I" to redefine the lost self (Baudelaire 9). Even, having call-response pattern, Juba dance can generally imply African Americans' flânerie when they are freely dancing or "working themselves up into a near frenzy" and communicating with others (Wilson 53). Reconnecting to the spirituality of Juba dance is a way of regaining African sensibility and thus a conduit for African American flâneur's self-recognition (Tyndall 135). Furthermore, flâneur's intense desire to extract eternal from transitory can meet its proper consummation in dancing (Tyndall 135); the dancing that detaches its performers from the limits of material world and move them to the eternal spirituality of African rituals (Young 142, 135).

II. Herald Loomis

The protagonist who is supposed to be the incarnation of Wilson's dramatic vision for showing the Africanness of African Americans in American society as a heeling tool is Herald Loomis (Tyndall 160). Henceforth, Loomis has undergone vicissitudes of identity formation through which his potential as flâneur has been fulfilled inasmuch as he can be hailed African American flâneur at the end of the play. In this sense, he is another African wanderer; "A man driven [...] by his search for a world that speaks to something about himself" (Wilson 14-15). He lost his wife due to his a seven _year_ sentence on Tennessee chain gang and now he is wandering to find her:

I just wanted to see your face to know that the world was still there. Make sure everything still in its place so I could reconnect myself together. / I just been waiting to look on your face to say my goodbye. [...] That goodbye kept me out on the road searching. [...] It kept me bound up to the road. (Wilson 91) 
While initially playing crucial role for desperate Loomis, this reunion seems unable to "sate his appetite" for wandering (Benjamin 417). So, it is turned into an end for Loomis to start up new beginning of following ceaselessly the road of roaming: "Now that I see your face, I can say my goodbye and make my own world" (Ibid.). Besides, at the initial part of the play, Loomis' answer to Bynum's question on his place of departure can attribute to his potential for flâneur who has "an immense joy to be in the ebb and flow of movement, in the midst of fugitive" (Baudelaire 9): "Come from all over. Whichever way the road takes us that's the way we go" (Wilson 160). Therefore, his initial goal of finding his wife is not to determine his way, stabilize the process of his life and justify his wandering in the road; however, as a station in which he will take up temporary residence to join the road again. Loomis's purposeful searching at the beginning of the play gradually seems to imply aimless purpose of searching and wandering which is the undeniable job of flâneur (Benjamin 417).

Most compelling evidence is Loomis's revolutionary state which is obvious through comparing stage descriptions of him in the first scene with that of the last scene:

$\mathrm{He}$ is unable to harmonize the forces that swirl around him, and seeks to recreate the world into one that contains his image. /Having found his song, the song of self-sufficiency, fully resurrected, cleansed and given breath, free from any encumbrance [...], having accepted the responsibility for his own presence in the world, he is free to soar above the environs that weighed and pushed his spirit into terrifying contractions. (Wilson 14, 94-95)

Accordingly, noticeable is Loomis' identity transformation from his initial convoluted state of inability to harmonize the world to a state of flâneur in satisfying his insatiable flânerie desire for "reordering and recreation" of his own song, religion, history and thus his own world (Tester 5). With this in mind, the initial definition of Loomis seems to denote his occupation with constellation of mental images drawn in floating and convoluted forces; The definition that cannot be dissimilar to early definition of flâneur proposed by Benjamin in the earliest phase of the Arcades Project. Accordingly, Benjamin's early flâneur is the intoxicated flâneur experiencing "colportage phenomenon of space", who has been enveloped in images after images (11). The cluster of images that has made him devoid of any historical role, more similar to Proustian "involuntary memory" in which "the object of the past 'sprang into being' in his cup 
of tea" (Benjamin11; Hanssen 10). Likewise, Loomis's past time of incarceration is constantly coming into being by present happening like Juba dance and Joe Turner's song. What is noteworthy to consider is, however, Benjamin's decision to "exchange the peregrinations of the intoxicated flâneur for the historical gaze" and to make correspondence between "the historic 'now'" and "the historic 'then' of recognizability" (463). Benjamin's changes have revolved figure of flâneur into a character having the time of awakening (Ibid). At this time of awakening, there is "the revolutionary completion of the past, the explosion of past possibility in the actuality of the present" (Hanssen 11). Likewise, Wilsonian agenda has prepared Loomis to reorganize and re-conceptualize his world through accepting his miserable past and finding his song. Actually, Loomis' triumph in recreation of his own world is claiming his identity and thus his own virtual property in the territory of host land (Nadel 2). This demand for rights is significantly suggestive of historicity of character in indirect protest against capitalism's commodification of Africans (Nadel 2). Essentially, Nadel's opinion finding Wilson's drama full of multifarious temporalities and images testifies the correlation between flâneur's Proustian thought-image and Wilsonian characters carrying their past into present land (14; Wilson xvi). To clarify, transformation of Baudelaire's flâneur into Benjamin's flâneur in dealing with convoluted spatial-temporal images has manifested identically in revolutionary process of Loomis' identity formation during the play.

Furthermore, the significant point is Loomis' name that is appropriately Herald Loomis (Bogumil 473). He became the one who "knows all that came before", the herald, and the shiny man possessing the "looming quality" (Ibid). More fascinating is the fact that the crucial figure for Benjamin is the one who is "a retrospective prophet" and a "herald who invites the dead [the past] to table" (481). Loomis is manifested as the shiny man that in Bynum's words "shines like new money [...] who "had a voice inside him telling him which way to go and if I come and go along with him, he was gonna show me the Secret of Life" (Wilson 9-10). Now as the complete manifestation of flâneur, Loomis is the same shining man Bynum's father necessitated to locate in his life and the "blind prophet who sees more than he knows" (Bogumil 473). After being identified as African American manifestations of Baudelaire's and Benjamin's flâneur, Bynum and Loomis configured by Wilsonian dramatic agenda are rendered to be analyzed from postmodern perspective of Deleuze and Guattari. 
III. African American Flâneur; Rhizomatic Life

1. Heterogeneous interconnections

As Deleuze and Guattari explain in a Thousand Plateaus, the rhizomatic elements are potentially eager to connect with any distinct elements, the kinds of connections and intersections that are multiple and random (9). In a similar vein, flâneur is interested in mingling with the crowd and having connectivity with others as "non-ego" (Tester 9; Baudelaire 9). Bynum, accordingly, is livening with members of boardinghouse with whom he has random unbiased connection, a kind of relation that can be equally justified by his role of being healer for all (Clark 71). Even, Bynum's multiple connections can be with contradictory characters or elements. His habit of singing Joe Turner's song demonstrates his peace with this divergent ominous figure evoking slavery trauma. Bynum's unrestricted connections with other are evinced by his story of encountering with that unknown man, later known as shiny man, during his journey and by an acceptance of the initial awkward song his father gave him (Wilson 71). Among these, the most seemingly incompatible conjunction is with Loomis. Loomis' outlook towards the world is in stark contrast with Bynum's while both are rendered to be each other's life consummation (Tyndall 164). Moreover, Juba dance can be also claimed to be a rhizomatic action due to the fact that its components are not homogeneous. Instead, its performers are the boardinghouse tenants with various socialeconomical differences (Gantt 7). As Bogumil concurs, the juba dance is generated from African's "absorptive culture" in which there isn't any division between members and "the great and powerful are in a sense leveled with the weak" (469; Cook 120). According to the concept of rhizome, there is expected not to be any "power takeover" or "state-form of organization" among these different members who peacefully perform this communal dance on Sundays (Deleuze and Guattari 8, 359; Wilson 52).

\section{Heterogeneous Multiplicities}

Given the fact that flâneur 's "struggle for existential completion [...] requires relentless bathing in multitude", his life can be identified as rhizomatic teeming with both temporal and spatial multiplicities, without any unification or organization (Tester 5, Deleuze and Guattari 9). To elaborate, having permanent experience of colportage phenomena of space or being called "chiffonnier", flâneur's kaleidoscopic gaze collects varying images of time and place while strolling around (Ibid. 15; Hanssen 163). Therefore, flâneur's wandering eagle eyes catch every scene and naturally store their 
snapshots in his mind to the extent that it turns into an archive of multiple unstructured heterogeneous images (Hanssen 123). Contrary to the arborescent model of representation (Deleuze and Guattari 8), rhizomatic nature of flâneur's cosmopolitan mind negates any imposition of power to unify its received multiple heterogeneous images. Accordingly, no temporal and spatial unification can be felt in Loomis and Bynum's narratives; we are merely informed of the "patchwork quilt" of their life in nonlinear chronology of time (Wilson 476). We don't know exactly when and where Bynum encountered the shiny man or Loomis' vision of bones happened. Even the images of space in the Bynum's narration of his past life cannot be easily referred to any specific area except to metaphysical world where everything was oversized (9). Thus, temporal-spatial multiplicities narrated in their story are devoid of any certain points since any attempt to unification is imposition of stratification and restriction opposite to flânerie itself (Deleuze and Guattari 8,249). Their development can also be expected to be in "unforeseen directions" (29)., so unpredictable is it that Bynum's lost shiny man capable of showing the secret of life can turn out to be Loomis (29). Enmeshing with this multitudes and heterogeneous mental images is the conduit for Wilson to rehistoricize Great Black Migration period from black refugee's outlook as "emancipatory century" (Scott 17).

Thus, the heterogeneity of components of their patchwork life is vital for tracing Loomis' evolutionary change into flâneur (Hanssen 59). Loomis has heterogeneous multiple images of his past life that all carry the memory of southern Africa: being venerable deacon of church, sharecropper, slave prisoner of Turner's system, his wife's absence and the vision of bones. All of these images are "outsiders" or "lines of flight" that are required for his further becoming and evolution in a road of salvation (Deleuze and Guattari 2, 9,249). Each line or being deterritorializes the territory of outsider to reterritorialize it for its own sake $(10,434)$. It is not the question of being African or American; it is the identity "that is perpetually in construction or collapsing, and of a process that is perpetually "prolonging itself, breaking off and starting up again." (21)

With this in mind and considering Wilson's "recursive" dramatic vision, in contrast to Rudolph's attempt at exploring the existence of dichotomy in Wilson's works between African traditional religion and Christianity (2013), present discussion is exploring the fact that Wilsonian images don't have "pristine identity of Christianity or Africanness" (Clark 48). It is not that pure identity for which characters would struggle to take "bi-univocalization", dual identity, or to follow 
the counterdiscursive philosophy of Rudolph's study (Richards 101; Holland 116). To illustrate, Richards explores "specific references to Yoruba belief system" in Wilson's diasporic text to claim that not only "Africa is always, already hybrid" but also Bynum is configuration of two disintegrated identities of Ogun and Esu (92). Therefore, the most dominate African features of Bynum is not so pure to prove homogeneity or duality of African American characters. Likewise, Wilson's dramatic agenda of providing Bynum and Loomis with "African sensibility" is not a promotion for privileged African versus American culture as Brustein misinterpreted Wilson's vision (Young 142). Thus, it is obvious that Wilson's dramatic vision is resonant of Deleuze and Guattari's double-becoming when he arranged Bynum and Loomis to construct new spiritual African space in America as African Americans (10). Constructing this spiritual space is in the light of their flânerie rhizomatic thought of deterritorialization and postmodern technique of simultaneous deconstruction and reordering, rejection and subversion of Western aesthetic (Shannon 23).

\section{Mapping Perspective of Flâneur's Gaze}

In order to have double-becoming in which there isn't any privileged thinking subject, the rhizomatic approach should be "cartographic or mapping" in contrast to "photographic or tracing" (Holland 40). It is also worthwhile to consider the different actual map that flâneur's mobility around the city can depict. Accordingly, his special panoramic gaze can rebuild "a cognitive mapping of newly expanded socio-economic relations" (Shields 75). In this sense, we can perceive that Plateaus' concept of mapping are bound to be resonance of flânerie since flâneur's "perambulating gaze" and kaleidoscopic consciousness are the acts of cartography themselves. The mapping has tendency to keep the mobility, multiplicities, heterogeneity and unforeseen nature of objects. In sharp contrast, tracing point of view attempts to neutralize the flexibility of multiples by virtue of predetermined principles "to simply reproduce the model itself" (Holland 40). Consequently, this inclination itself shows mapping's inherent orientation towards experimentation rather than "repetition in contact with reality" (Ibid). Likewise, flâneur's joy to be in the multitude and his historical gaze as materialist historian follow mapping technique. With this in mind, flâneur's essential goal is not the mere representation of "some bygone era" but to reconstruct the past while blasting it out of "homogeneous course of history" and disturbing the stability of the past (Hanssen 19). Accordingly, that is why Bynum propels Loomis to experiment the mobility of his traumatic past 
instead of neutralizing that Moreover, Bynum's flânerie eyes are qualified with mapping outlook believing that every African Americans has their own song, "secret of life" and is not restricted to stiff categorization of nigger (Wilson11,22). In this light, to Bynum's cartographic view the most seemingly divergent Loomis can be turned out to be the confirming convergent line of progress in his life when Loomis is manifested as his lost shiny man.

4. Loomis' Redemption; transformation from stratification to destratification:

With more concentration on initial Loomis as a potential flâneur, it is worthwhile to explore how Bynum's rhizomatic thought supports him to experience the moment of epiphany and thus salvation. "Wandering a long time in somebody else's world" and searching for her wife as a starting place for his life, Loomis can be characterized as a potential flâneur (Wilson 73). He was recently a wanderer or would-be flâneur in Joe's world which he hates and wants to leave. Nevertheless, Bynum wants him to accept his servitude in the south. That is a torment that plays as the rupture part of the rhizomatic life in function of medium of survival and of retrieving self (Gantt 9). Loomis is searching for a beginning or definite destination while Bynum's advice turns him into moving and in the road: "Everybody's standing and walking toward the road. What you gonna do, Herald Loomis? (Wilson 56)". In rhizomatic philosophy, there would not be any point but a continuous line of wandering which can strongly allude to flânerie as the ceaseless questing (Deleuze and Guattari 8). Like the materialist historian and rhizome, Loomis should follow the lines of multiplicities in his past and let them undergo possible transformation to turn into his own territory and becoming. His previous wandering in Turner's world is the prerequisite of his new continuous wandering that as a line of flight should be deterritorialized. Then, after being developed into that unstructured patchwork, those ruptures lead to his evolution rather than his stratification and subjectification as slave subject (476).

In this sense, listening to Loomis speaking about his nightmare, Bynum realizes how Loomis is hunted by Turner and not able to evaluate his individual song: "What he wanted was your song. He wanted to have that song to be his" (Wilson 75). It is in this part that Bynum's rhizomatic view and belief in double- becoming instead of belief in sticking to binary opposition of colonizer/colonized for survival is significantly observable. The relationship between Joe and Loomis is that of "wasp and orchid" in that one becomes "the subject of a becoming-the-other" without imposing compulsion on the other 
(Deleuze and Guattari 293; Holland 67, 106, 105, 39). As Bynum states, Joe's reason for capturing the niggers was to learn their song, to deterritorialize Loomis' song and by decoding that he made it his own territory and state of power (Deleuze and Guattari 10). However, this connection cannot lead to any double becoming devoid of any power takeover since Loomis as wasp hasn't yet functioned to deterritorialize Joe's territory and consequently got to his own song and identity (9). Here, Bynum is trying to invite Loomis to remember his song and make it of his own by making parallel rather than dual connection with Joe as an intersection during his rhizomatic wandering life. It is at the end of the play that Loomis' manifestation as flâneur or becoming into shiny man proves his constant wandering. he has said goodbye to his wife and passed her as one of those ruptures in his way to further becoming (La Rue 34): "That goodbye kept me out on the road searching. / Now that I see your face, I can say my goodbye and make my own world" (Wilson 91).

After confirming his miserable unrelieved past and rhizomaticly recognizing those binding not as an impasse but transient, Loomis deterritorialized them. As a matter of fact, Loomis has the process of "self-dismantling" through encountering the torment of his past. To relocate his own territory in the present, he deterritorializes his past identity while preventing it from acting as restriction than a medium of emancipation: "Well, Joe Turner's come and gone and Herald Loomis ain't for no binding. I ain't gonna let nobody bind me up! (93)

Equally important to notice is the same process of constant destruction and reconstruction of self through deterritorialization of Christianity to reterritorialize it for his own sake. As Young concurs, Loomis needs to "overcome his own blind submission to a biased God" (132). Therefore, in response to Martha's sermon Loomis says: "That's ("the shadow of death") just where I be walking!" (Wilson 93). Here, dying for Loomis is destruction of the self which was captured by Joe's system, from which he can rebirth and experience his becoming. Another compelling evidence is Loomis' critique on Christ's promise of salvation by describing the misery of slavery scene he had experienced before:

[...] what a nice man Mr. Jesus Christ is 'cause he give him salvation after he die [...] Something don't fit right! / I done been baptized with blood of the lamb and the fire of the Holy Ghost. But what I got, huh? "(94).

Loomis's aggressive words on the Holy God and Christianity should be signified more as the act of "rhizome-root assemblage" 
(Deleuze and Guattari 15). It is an assemblage in which he "bolster" himself through breaking strict root or rule to "make new connection", reconstruct his own religion and thus to regain self (Bogumil 465).

In the process of deterritorialization, instead of applying Christian baptism's cleansing, Loomis uses his own blood or his Africanity for his salvation and in doing this "comes to realization" and says "I'm standing! I'm standing. My legs stood up! I'm standing now!" (Wilson 94). Similarly, it evokes flâneur's essential intoxication for reordering whatever his forensic gaze catches (Tester 4). Recreating his own world to restore his tradition of endless flânerie is essentially rhizomatic in that it "undergoes metamorphosis" to expand its dimension and thus his being as unbounded flâneur (Deleuze and Guattari 21). Accordingly, Loomis as African American flâneur set his own world as his initial wish but was unable to achieve until he can reconnect with his slavery past and outside lines in his journey. Based on Wilson's stage note, Loomis has no burden or "encumbrance" when he has "accepted the responsibility for his own presence in the world" and when he is free from any "soar" or anything that "pushes his spirit into terrifying contractions" (Wilson 94). Those "terrifying contradictions" are the ruptures Loomis deterritorialized to regain his identity and triumph. Furthermore, it is worthwhile to consider Wilson's further stage note that Loomis has found "the song of selfsufficiency, fully resurrected, cleansed and given breath (93). Accordingly, we can indicate that those encumbrances are not Joe, Christianity or the abolition system themselves but their denial. Strictly speaking, it is the "biunivocal relationship between positions" of Black/White that makes a burden for Loomis and other African Americans and pushes their "spirit into terrifying contractions" (Deleuze and Guattari 21). In other words, that burden is following sedentary system of stratifying the mobility of multiplicities, frequently practiced by slavery system (13). It is at this moment that Loomis, freeing himself from "the stratum of subjectification, moves to stratum of free experimentation and autonomy" (Holland 99). He is transformed into new becoming of African American flâneur or the shiny man as Bynum recognizes: "Herald Loomis, [...] You shining like new money!" (Wilson 94).These are flâneur's wandering "nonpossessive", de-stratified perception to the world (Hanssen 207; Holland 96) and African heritage of disintegrated heterogeneous identity (Richards 98) that have qualified Wilsonian characters to be set in the rhizomatic thought and gain their emancipation in cosmopolitan world of America. 


\section{CONCLUSION}

The figure of flâneur is so replete with multifaceted features and versatility that it can take temporal-spatial transgression to be manifested in multiple incarnations. African American incarnation is appropriate accommodation for flâneur since it inherently has ceaseless wandering, existential questing, multiplicity and collective identity of flâneur in its African heritage. Concentration of Plateaus' rhizome on permanent multiple connections with lines of flight to move from stratification to autonomy can appropriately denotes African American flâneur. Consequently, those are hailed rhizomatic Wilsonian flâneurs that experiment multiple constant becomings. Bynum and Loomis's wandering beings as African American flâneurs is bound to continue in more random connections with various lines of multiplicities in which there are neither a beginning nor an end. Consequently, these lines of connections and other lines of flight overlap and intertwine with each other to the extent that "a multiplicity is continually transforming itself into a string of other multiplicities" in this patchwork (Deleuze and Guattari 249). That is the reason why Bynum as a flâneur is still following flânerie and as a shiny man is still looking for the shiny man to get more development and thus change into another multiplicity. That is the reason why Wilsonian characters are mirroring the rhizome which "operates by variation, expansion, conquest, capture and offshoots" (21). Flâneur's life is open and unrestricted as rhizome's dimensions are connectable. Flâneur's considerable adaptability and African American's experimental African nature set up symbiotic relationship between flâneur and Wilsonian characters. It is this vital symbiotic relationship that can disclaim the binary opposition of American/African and instead proclaim rhizomatic double becoming.

\section{REFERENCES}

Baudelaire, Charles. The Painter of Modern Life: and Other Essays. (TR \&Ed) J. Mayne. Phaidon.1970.

Benjamin, Walter. The Arcades Project. (Translated) H. Eiland and K. McLaughlin. Belknap P: Harvard Uni. P,1999.

Bogumil, Mary. L." 'Tomorrow Never Comes': Songs of Cultural Identity in August Wilson's Joe Turner's Come and Gone". Theatre Journal 46.4(1994):463-76.

http://www.jstor.org/stable/3209070 
Cervenak, Sarah Jane. Wandering: Philosophical Performances of Racial and Sexual Freedom. Duke U P.2014.

Clark, Keith. "Race, Ritual, Reconnection, Reclamation: August Wilson and the Refiguration of the Male Dramatic Subject". Bloom's Modern Critical Views August Wilson, Ed. Harold Bloom. Infobase Publishing,43-76.2009.

Deleuze, Gilles and Felix Guattari. a Thousand Plateaus Capitalism and Schizophrenia. Trans. B. Massumi. London: U of Minnesota P, 1987.

Gantt, P. Ghosts from "Down There": The Southernness of August Wilson". Bloom's Modern Critical Views August Wilson. Ed Harold Bloom. New York: Infobase Publishing, 2009.5-19.

Hanssen, Beatrice. Walter Benjamin and the Arcades Project. London: Continuum, 2006.

Holland. Eugene W. Deleuze and Guattari's A thousand plateaus a reader's guide. London: Bloomsbury Publishing,2013.

Ibrahim, Awad. "The New flâneur." Cultural Studies 22.2(2008):234253. doi:10.1080/09502380701789141.

Lane, Jill. (2002). "Reverend Billy: Preaching, Protest, and Postindustrial Flânerie." TDR/The Drama Review 46.1(2002): 60-84. doi:10.1162/105420402753555859

Larue. Rubert. Moving beyond this Moment: Employing Deleuze and Guattari's Rhizome in Postcolonialism. U of Texas, Arlington. 2011.

Lee, Changnam. (2017). "Introduction: The Transnational Flâneur." Sociétés135.1 (2017): 5-7. doi: 10.3917/soc.135.0005.

Nadel, Alan. "Beginning Again, Again Business in the Street in Jitney and Gem of the Ocean". August Wilson: Completing the Twentieth-Century Cycle, Ed A. Nadel. U of lowa P: lowa City, 2010.14-29.

. "Reading August Wilson's Character and His Characters: A Suggestive Introduction". August Wilson Journal1.1(2019): 335.DOI 10.5195/awj.

Prece, Paul. Writing Home: The Post Colonial Dialogue of Athol Fugard and August Wilson. Published Thesis, U of Kansas, 2008.11-36.

Pinkney, Mikell. (2004). "The Development of African American Dramatic Theory: W.E.B. DuBois to August Wilson-Hand to Hand!". August Wilson and Black Aesthetics, Eds. S. Shannon and D. A. Williams. New York: Palgrave Macmillan,2004.

Rechniewski, Elizabeth. "When and why did the flâneur die? a Modern Detective Story". Literature \& Aesthetics17.2 (2007): 90-103. 
Richards, Sandra L. "Yoruba Gods on the American Stage: August Wilson's Joe Turner's Come and Gone". Research in African Literatures30.4 (1999): 92-105.

Rudolph, Amanda M. (2003). "Images of African Traditional Religions in Joe Turner's Come and Gone and the Piano Lesson". Journal of Black Studies 33.5(2003): 562-575.doi:

$10.1177 / 0021934703251106$

Schipper, Imanuel. "From Flâneur to Co-Producer: The Performative Spectator." Performing the Digital Transcript Verlag, Eds. M. Leeker, I. Schipper and T. Beyes.2017.191-209.Retrieved Jul 30, 2019 from https://www.jstor.org/stable/j.ctv1xxsxb.12

Scott, Joyce Hope "The emancipated century": remapping History, reclaiming Memory in August Wilson's Dramatic Landscapes of the 20th Century. August Wilson's Pittsburgh Cycle Critical Perspectives on the Plays" Ed. S.G. Shannon. Jefferson: McFarland, 1972.15-38.

Shannon, Sandra G. "Audience and Africanisms in August Wilson's Dramaturgy: A Case Study". Bloom's Modern Critical Views August Wilson Ed. H. Bloom. New York: Infobase Publishing, 2009. 21-42.

Shannon, Sandra. G, Williams D.A. "A Conversation with August Wilson". August Wilson and Black Aesthetics Eds. S.G. Shannon and D.A. Williams. New York: Palgrave Macmillan.2004.187195.

Shields, Rob. "Flânerie for Cyborgs." Theory, Culture \& Society 23.78(2006): 209-220. doi:10.1177/0263276406069233.

Snodgrass, Mary Ellen. August Wilson: A Literary Companion. McFarland, 2006.

Steinman, Kevin. Reviving the Flâneur New identities for the Modern Urban Stroller in James Joyce's Ulysses, Christopher Isherwood's Goodbye to Berlin and Jean Rhys's Good Morning Midnight. U of Oslo, 2014. Published Thesis.

Suárez, Isabel Carrera. "The Stranger Flâneuse and the Aesthetics of Pedestrianism." Interventions 17.6(2015): 853-865. doi: 10.1080/1369801x.2014.998259.

Tester, Keith. Routledge Library Editions: Social Theory: The Flaneur. Vol23. Routledge: London and New York,2014.

Tyndall, C. Patrick. "Using Black Rage to Elucidate African and African American Identity in August Wilson's JOE TURNER'S COME AND GONE (1911)". August Wilson: Completing the TwentiethCentury Cycle Ed D.A. Williams. U of lowa P: lowa City, 2010. 30-40. 
Wilson, August. Joe Turner's Come and Gone. Plume, 1988.

Young, Reggie. "Phantom Limbs Dancing Juba Rites in August Wilson's Joe Turner's Come and Gone and The Piano Lesson". August Wilson and Black Aesthetics Eds. S. Shannon and D. A. Williams 129-143.Palgrave Macmillan, 2011.

\section{RIZOMATSKI KOSMOPOLITSKA I VILSONOVSKI REKURZIVNA VIZIJA U KOMADU DOLAZAK I ODLAZAK DŽOA TARNERA}

Biti konstantno tragač za izgubljenim identitetom u multietničkoj zemlji kakva je Amerika Afroamerikance upadljivo približava figuri tzv. flâneura uključujući i elemente dijalektičke slike lokalnog i kosmopolitskog građanina univerzuma. Duh flânerie doživljava svoju geografsko-istorijsku ekspanziju i u postmodernom i u afroameričkom kontekstu, dok ga njegova performativna akcija usmjerava ka dramskom kontekstu. Otud vilsonovski karakteri, izjednačeni sa stalnom egzistencijalnom potragom za izgubljenim sopstvom, mogu biti američke inkarnacije flâneura. Oslanjajući se na Bodlerovu definiciju i Benjaminovu teoriju flâneura, ova studija teži da ukaže na moguće manifestacije afroameričkog flâneura u drami Augusta Vilsona Dolazak i odlazak Džoa Tarnera (1986). Dodatno, posredstvom postmodernog teorijskog koncepta rizoma Deleza i Gatarija izloženog u djelu Thousand Plateau (1987), studija ima namjeru da istraži postmodernu manifestaciju flâneura i konsekventno pokaže kako vilsonijanska postmoderna rekurzivna dramska vizija funkcioniše kao sredstvo reprezentacije misterioznih aspekata afroameričkog života. Mnogoznačnost pojma flâneur odgovara suštinskoj manifestaciji Afroamerikanaca utoliko što se višestrukost afričke prirode potonjega može prilagoditi fleksibilnosti prvoga.

Ključne riječi: Avgust Vilson, Bodlerov flâneur, Benjaminov flâneur, Delez i Gatari: Hiljadu platoa, Dolazak i odlazak Džoa Tarnera, rizom. 